\title{
REVIEW
}

\section{Current Concepts of Osteomyelitis}

\section{From Pathologic Mechanisms to Advanced Research Methods}

\author{
Marloes I. Hofstee, ${ }^{\star \dagger}$ Gowrishankar Muthukrishnan, ${ }^{\ddagger}$ Gerald J. Atkins, ${ }^{\S}$ Martijn Riool, ${ }^{\dagger}$ Keith Thompson, ${ }^{*}$ Mario Morgenstern, \\ Martin J. Stoddart, ${ }^{*}$ Robert G. Richards, ${ }^{*}$ Sebastian A.J. Zaat, ${ }^{\dagger}$ and Thomas F. Moriarty* \\ From the AO Research Institute Davos, * Davos, Switzerland; the Department of Medical Microbiology, ${ }^{\dagger}$ Amsterdam UMC, University of Amsterdam, \\ Amsterdam Infection and Immunity Institute, Amsterdam, the Netherlands; the Center for Musculoskeletal Research and Department of Orthopaedics, ${ }^{\ddagger}$ \\ University of Rochester Medical Center, Rochester, New York; the Centre for Orthopaedic and Trauma Research, ${ }^{\S}$ University of Adelaide, Adelaide, South \\ Australia, Australia; and the Department of Orthopedic Surgery and Traumatology, "University Hospital Basel, Basel, Switzerland
}

\author{
Accepted for publication \\ February 27, 2020. \\ Address correspondence to \\ Thomas F. Moriarty, Ph.D., AO \\ Research Institute Davos, Clav- \\ adelerstrasse 8, 7270 Davos-Platz, \\ Switzerland. E-mail: fintan. \\ moriarty@aofoundation.org.
}

\begin{abstract}
Osteomyelitis is an inflammation of the bone and bone marrow that is most commonly caused by a Staphylococcus aureus infection. Much of our understanding of the underlying pathophysiology of osteomyelitis, from the perspective of both host and pathogen, has been revised in recent years, with notable discoveries including the role played by osteocytes in the recruitment of immune cells, the invasion and persistence of $S$. aureus in submicron channels of cortical bone, and the diagnostic role of polymorphonuclear cells in implant-associated osteomyelitis. Advanced in vitro cell culture models, such as ex vivo culture models or organoids, have also been developed over the past decade, and have become widespread in many fields, including infectious diseases. These models better mimic the in vivo environment, allow the use of human cells, and can reduce our reliance on animals in osteomyelitis research. In this review, we provide an overview of the main pathologic concepts in osteomyelitis, with a focus on the new discoveries in recent years. Furthermore, we outline the value of modern in vitro cell culture techniques, with a focus on their current application to infectious diseases and osteomyelitis in particular. (Am J Pathol 2020, 190: 1151-1163; https://doi.org/10.1016/j.ajpath.2020.02.007)
\end{abstract}

Osteomyelitis is an infectious disease affecting bone and bone marrow, ${ }^{1}$ with Staphylococcus aureus being the causative pathogen in $30 \%$ to $60 \%$ of cases in humans ${ }^{2}$ and staphylococci collectively causing approximately $75 \%$ of cases. $^{3}$ Osteomyelitis generally develops from a hematogenous or traumatic source. ${ }^{1,4}$ Hematogenous osteomyelitis most often occurs in children aged $<16$ years as the result of hematogenous spread of bacteria (eg, due to bacteremia). ${ }^{1}$ The second route, traumatic, may occur secondary to fractures or surgery. ${ }^{4}$ Herein, the protective barrier of the skin is disrupted, allowing contaminating bacteria to enter the wound and invade bone tissue. ${ }^{4}$ In fact, all orthopedic surgeries are at risk of developing osteomyelitis via the traumatic route because of the risk of bacterial translocation from the skin to the surgical site intraoperatively. ${ }^{4}$

Osteomyelitis patients may display clinical symptoms, such as pain, swelling, purulent drainage, fistula and/or sinus presence, wound breakdown, erythema, and increased local temperature. ${ }^{5,6}$ In addition, the following parameters are considered: i) signs of bone destruction and the presence of sequestra and purulent collection in soft tissue assessed with imaging, ii) occurrence of organisms in more than one deep specimen verified with microbiological cultures, and iii) leukocyte counts, erythrocyte sedimentation rate, and C-reactive protein levels. ${ }^{5,6}$ Infection can be confirmed by histopathologic examination of deep tissue samples; the presence of microorganisms in deep tissue is examined using specific staining techniques for bacteria (eg, Gram stain or Ziehl-Neelsen stain for tuberculosis) or fungi (eg, Grocott methenamine silver stain). ${ }^{7}$ For culture-negative patients, the diagnosis of osteomyelitis can be confirmed histologically if there are signs of active bone resorption and

\footnotetext{
Supported by AOTrauma grant AR2017_05 as part of the Clinical Priority Program on Bone Infection.
}

Disclosures: None. 
remodeling and the presence of acute and chronic inflammatory cells. ${ }^{5}$ Acute inflammatory cell infiltrate is demonstrated by identifying more than five polymorphonuclear cells (PMNs) per high-power ( $\times 400$ magnification) field. ${ }^{8}$ This criterion is also used for other orthopedic infections, such as periprosthetic joint infections ${ }^{9}$ and chronic/lateonset fracture-related infections. ${ }^{6}$ The complete absence of PMNs strongly correlates with aseptic nonunion (specificity, 98\%; positive predictive value, $98 \%){ }^{6}$

Treatment regimens in acute, uncomplicated cases of osteomyelitis may consist of antibiotic therapy alone if preconditions are met, ${ }^{5}$ which is typically administered for 4 to 6 weeks and is associated with a success rate of approximately $80 \% .^{4}$ In contrast, for chronic and for implant-associated osteomyelitis, the success of antibiotic therapy alone is relatively low and requires debridement (ie, surgical removal of infected bone and implant components) to achieve satisfactory success rates. ${ }^{4}$ These debridement or revision surgeries are often challenging, given that the extent of bone debridement can be difficult to judge, and the management of the resultant dead space can also require complex interventions and prolonged healing time. ${ }^{4}$ Despite best practice in medical and surgical therapy, there remains a $20 \%$ chance of treatment failure in such complicated cases. $^{10}$

Our understanding of the pathophysiology of osteomyelitis has evolved over recent years, and we now have a better insight into why chronicity and the presence of an implant require more vigorous treatment. For instance, we know that bacterial biofilm formation and bacterial invasion within the osteocyte lacuna-canalicular system are involved in chronic osteomyelitis. ${ }^{11}$ Furthermore, the host response to the infection and subsequent changes in bone morphology (eg, sequester or involucrum formation) are also better understood at the present time. Much of this new understanding of the underlying pathophysiology of osteomyelitis (eg, bone turnover, osteolysis, and bacteriological changes over time) has been determined from histologic analyses of individual human specimens ${ }^{12-14}$ and laboratory animal studies. ${ }^{15,16}$

In other fields, advanced in vitro cell culture models have been developed to reduce our overreliance on laboratory animals. In particular, three-dimensional (3D) cell culture has become a standard in the fields of tissue engineering and cancer biology, where the organotypic 3D constructs have been shown to i) have their own microenvironment, ii) resemble in vivo tissue organizations, and iii) have cellular behavior that more faithfully reflects the in vivo setting. When using human cells, these systems may be more reflective of the human situation than currently used preclinical in vitro two-dimensional culture systems. ${ }^{17}$ These models could also serve to improve our understanding of osteomyelitis, although until now, only one study has used an advanced cell culture system to study osteomyelitis, ${ }^{18}$ to the best of our knowledge.

In this review, we describe the pathophysiology of osteomyelitis and the currently used in vitro systems for osteomyelitis research, with the focus on the most recent discoveries and improved mechanistic understandings of the pathophysiology of osteomyelitis. Furthermore, we review published advanced multicellular in vitro models and their potential to further our understanding of human osteomyelitis, without requiring the use of experimental animals.

\section{Pathophysiology of Osteomyelitis}

\section{Pathogen Factors}

Staphylococcus aureus arriving at the bone surface via iatrogenic or hematogenous routes can readily adhere to soft tissue, bone, ${ }^{1}$ or metal implants. ${ }^{19}$ The bacterium may achieve this through binding to extracellular matrix (ECM) proteins via microbial surface components recognizing adhesive matrix molecules, such as collagen-binding protein and bone sialoprotein binding protein. ${ }^{20}$ Herein, S. aureus employs multiple survival strategies to not be affected by immune cells and therapies (Figure 1A). Adherent S. aureus may multiply, aggregate, and form microcolonies, ${ }^{15,21}$ which are also known as staphylococcal abscess communities (SACs) (Figure 1D). ${ }^{22,24}$

SACs are not exclusively found in bone tissue; they have been observed in skin, kidney, renal, and brain tissues. ${ }^{25-27}$ In most cases, the SACs form the center of an abscess structure with surrounding fibrin deposits. ${ }^{25,27,28}$ Specifically, $S$. aureus can form fibrin by promoting polymerization of fibrinogen and secreting enzymes, such as coagulase and von Willebrand factor-binding protein, which activate endogenous prothrombin and contribute to fibrin formation. This fibrin network surrounding the bacterial SACs protects the bacteria from invasion and clearance by immune cells, such as PMNs, ${ }^{25}$ causing the immune cells to gather around the bacterial nidus (Figure 1D)..$^{2,25-27}$

Staphylococcus aureus adhering to implanted devices or sequestra may form an even more complex structure known as a biofilm (Figure 1D). ${ }^{1,23}$ Bacteria in biofilms are less susceptible to antibiotics, because of several factors, including reduced oxygen levels and metabolism. ${ }^{29}$ Furthermore, $S$. aureus resident in biofilm may secrete the so-called extracellular polymeric substance matrix consisting of self-produced polysaccharides and proteins and possibly extracellular DNA from dead bacterial cells, forming a matrix that functions as a physical barrier to immune cell infiltration. ${ }^{29}$

Besides clustering in SACs or into biofilm, S. aureus can also invade the osteocyte-lacuno canaliculi networks within bone (Figure 1D). ${ }^{11,30}$ Recently, invasion of $S$. aureus in the submicron channels buried deep within the dense mineral matrix of cortical bone has been discovered. ${ }^{11,30}$ Invasion of $S$. aureus within the canalicular network could be a mechanism to promote persistence and chronic infection, with the potential to limit access to immune cells. This novel persistence mechanism was originally identified in a mouse model of implant-associated osteomyelitis, and was 
A

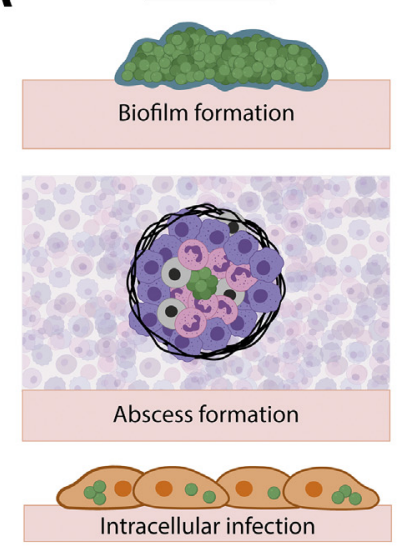

D
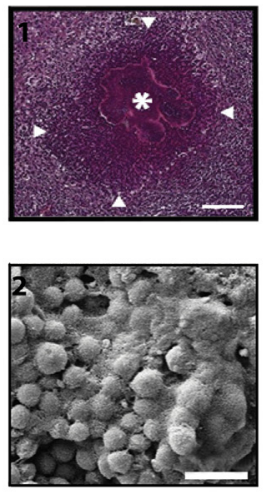

B
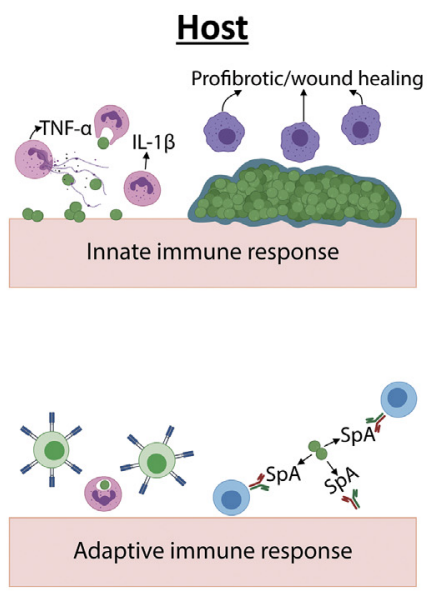

Overview

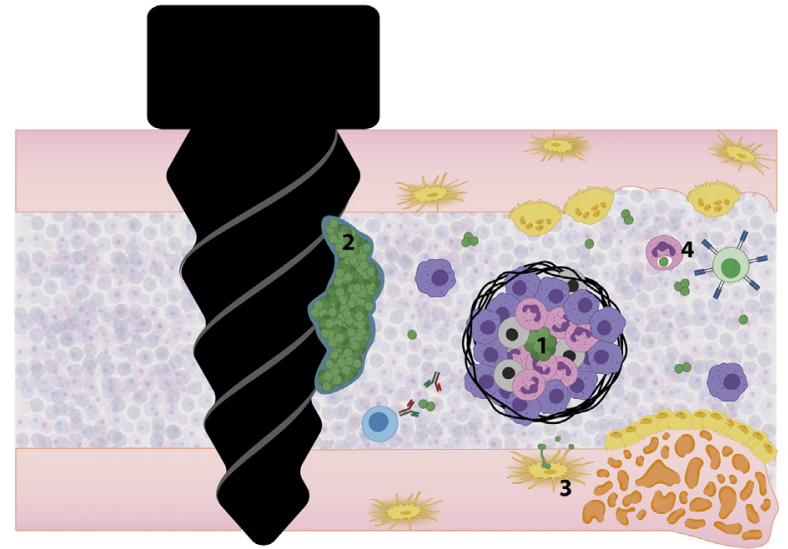

C
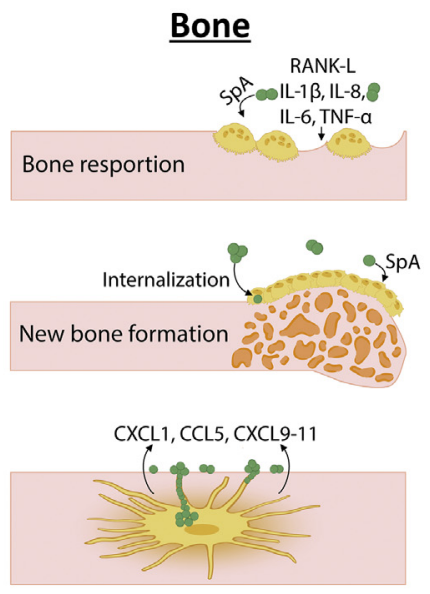
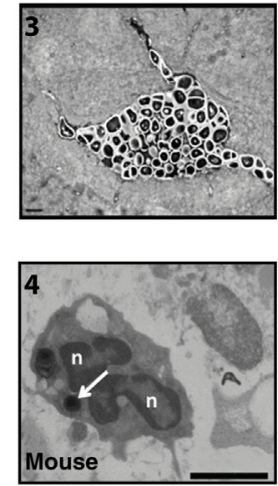

Figure 1 A mechanistic illustration of the pathophysiology of osteomyelitis. A: Bacteria: survival strategies of Staphylococcus aureus in bone to circumvent immune cell responses and therapies are i) forming biofilm that contains an extracellular polymeric substance matrix, ii) growing as staphylococcal abscess communities (SACS) as part of an encapsulated abscess, or iii) performing intracellular colonization of host cells. B: Host: bacterial presence in bone initiates an influx of innate immune cells. During acute inflammation, polymorphonuclear cells (PMNs) predominate, and during chronic inflammation, macrophage numbers increase. PMNs secrete proinflammatory cytokines, including IL-1 $\beta$ and tumor necrosis factor (TNF)- $\alpha$, and release neutrophil extracellular traps (NETs) to facilitate bacterial killing. Macrophages are skewed toward a wound healing and profibrotic phenotype. Adaptive immune responses include T- and Bcell responses. However, T-cell responses are skewed by $S$. aureus toward type 1 and type 17 helper T cell biased immune responses. Staphylococcus aureus protein A (SpA) binds to antibodies secreted by B cells and consequently blocks antibody-mediated phagocytosis. C: Bone: bacterial presence promotes i) host cells to secrete probone resorptive cytokines, causing, together with SpA binding, bone resorption by osteoclasts, ii) osteoblasts to form new bone because of internalization of the bacterium and SpA binding, and iii) secretion of the chemoattractants C-X-C motif chemokine ligand 1 (CXCL1) and C-C motif chemokine ligand 5 (CCL5) for PMN recruitment and CXCR3-binding chemokines CXCL9, CXCL10, and CXCL11 for T-lymphocyte recruitment by (invaded) osteocytes. D: An overview of the different osteomyelitis components accompanied by in vivo images of the following: 1, a staphylococcal abscess commu (SAC) (asterisk) surrounded by immune cells (arrowheads), as observed in a hematoxylin and eosin stained paraffin-embedded section containing an S. aureus infected murine femur $^{22} ; 2$, biofilm on a polyether ether ketone fixation plate imaged with scanning electron microscopy ${ }^{23} ; 3$, S. aureus within an osteocyte canaliculus ${ }^{11}$; and 4, S. aureus bacterium (arrow) within a PMN, ${ }^{15}$ both observed with transmission electron microscopy. Green cells, S. aureus; black strands, fibrous tissue; gray cells, dead cells; pink cells, PMNs; purple cells, macrophages; orange cells, generic cells; pink cell with purple/gray strands, PMNs undergoing NETosis; light green cells, T cells; blue cells, B cells; multinuclear yellow cells, osteoclasts; yellow cells, osteoblasts; elongated yellow cells, osteocytes. D: Image 1 reprinted from Brandt et $\mathrm{al}^{22}$ with permission (Copyright 2018. The American Association of Immunologists, Inc.); image 2 reprinted from Inzana et $\mathrm{al}^{23}$ with permission; image 3 reprinted from de Mesy Bentley et $\mathrm{al}^{11}$ with permission; and image 4 reprinted from Horst et al ${ }^{15}$ with permission. Images in $\mathbf{A}-\mathbf{C}$ and the schematic in D were generated with BioRender (Toronto, ON, Canada). Scale bars: $100 \mu \mathrm{m}$ (D, image 1); $2 \mu \mathrm{m}$ (D, images 2 and 4); $1 \mu \mathrm{m}$ (D, image 3). $\mathrm{n}$, nucleus; RANK-L, receptor activator of NF-KB ligand.

subsequently confirmed in a human $S$. aureus diabetic foot infection. ${ }^{11,30}$ This discovery is particularly concerning in the context of $S$. aureus osteomyelitis, as these canalicular networks may be impenetrable by immune cells, and bacteria can possibly survive in this space for a long period of time, using bone matrix as a nutrient source. ${ }^{30}$ However, this has not been proved yet.
As another defense mechanism, S. aureus has a wide range of toxins that target host cells. These toxins include exfoliative toxins, pore-forming toxins, and superantigens. ${ }^{31}$ The superantigen toxic shock syndrome toxin 1 has been associated with bone infection. ${ }^{32}$ It has been shown that toxic shock syndrome toxin 1 can promote osteoclastogenesis and bone resorption activity of osteoclasts in vitro. ${ }^{32}$ 
Also, pore-forming toxins have been linked to bone infection. ${ }^{32}$ Staphylococcus aureus pore-forming toxins can be subdivided into leukotoxins, hemolysin- $\alpha$, hemolysin- $\beta$, and phenol-soluble modulins; and these proteins affect host cell membrane integrity. ${ }^{31}$ For phenol-soluble modulins, it has been demonstrated in vitro to have a cytotoxic effect on osteoblasts, whereas the hemolysin- $\alpha$ caused both osteoblast and osteoclast cell death in vitro. ${ }^{32}$ Hemolysin- $\beta$ may be involved in phagosomal escape, as shown in vitro in PMNs, and in vivo it stimulated biofilm formation. ${ }^{31}$ Furthermore, human osteomyelitis patients infected with an $S$. aureus strain that can secrete the leukotoxin Panton-Valentine leucocidin had a more aggressive and more difficult to treat infection. $^{32,33}$

In addition, S. aureus can invade and survive intracellularly in professional phagocytes, ${ }^{15,34}$ as well as nonprofessional phagocytes (Figure 1D). ${ }^{35,36}$ Staphylococcus aureus triggers phagocytic internalization by expressing fibronectin-binding proteins (A and $\mathrm{B}$ ), adhering to fibronectin, and connecting to $\alpha_{5} \beta_{1}$ integrins on macrophages or neutrophils. ${ }^{37}$ After internalization, $S$. aureus evades cell death in these cells by persisting within vacuoles or by inhibiting phagolysosomal fusion. ${ }^{38}$ It can also infect and survive within non-professional phagocytes, such as primary human osteoblasts in vitro, ${ }^{35}$ mouse osteoclasts in vitro ${ }^{39}$ and in vivo, ${ }^{38}$ and human osteocytes in vitro and ex vivo. ${ }^{36}$ This intracellular persistence provides the pathogen with crucial protection needed against the onslaught of the immune system and antibiotic treatments. Staphylococcus aureus -infected human osteoblasts may also mature into osteocytes and remain infected. ${ }^{40}$ To survive intracellularly, S. aureus frequently adopts a dormant small colony variant phenotype, characterized by slow growth and reduced metabolic activity. ${ }^{41}$ The numerous mechanisms by which $S$. aureus is able to survive intracellularly within the bone niche for long periods is a primary cause of chronic and recurrent osteomyelitis.

\section{Host Factors}

The presence of bacteria within the bone tissue triggers a host response, which encompasses an innate immune response primarily driven by PMNs, macrophages, and adaptive responses mediated by $\mathrm{T}$ cells, $\mathrm{B}$ cells, and pathogen-specific antibodies (Figure 1B).

First, on bacterial recognition, resident macrophages in bone, ${ }^{42,43}$ osteocytes, ${ }^{36}$ and osteoblasts ${ }^{43,44}$ all appear able to secrete chemoattractants to initiate an influx of immune cells to the site of infection. An influx of PMNs during acute osteomyelitis occurs in both humans ${ }^{12,13}$ and in rodent osteomyelitis models. ${ }^{15,16}$ Inflammatory macrophages [myeloid related protein 8 (MRP8)/MRP14 positive] and CD4 T cells, potentially activating PMNs, ${ }^{14}$ have also been observed in humans ${ }^{12}$; and many necrotic immune cells are present in rodent osteomyelitis models. ${ }^{15,25,27}$ PMNs can efficiently kill planktonic $S$. aureus via phagocytosis, oxidative bursts, and production of antimicrobial peptides, whereas secretion of proinflammatory cytokines and chemokines, such as tumor necrosis factor (TNF)- $\alpha$, IL-1 $\beta$, CXCL2, CXCL3, and others, activates and recruits PMNs, which ultimately leads to pathogen clearance. ${ }^{45}$ PMNs and macrophages also elicit direct host defense responses by forming neutrophil extracellular traps, to trap bacteria, which are eventually cleared by immune cells. ${ }^{46,47}$

As the infection persists and becomes chronic, bacteria tend to form a biofilm phenotype, and the influx of viable PMNs decreases drastically, as demonstrated in mice and observed in humans with chronic osteomyelitis. ${ }^{12,15,16}$ In humans, most cells present at the site of chronic infection are wound-healing M2 macrophages (CD163 positive), accompanied by a small number of CD8 T cells and plasma cells. $^{8,12,13}$ The predominant M2 macrophages are inefficient in phagocytosing bacteria within the biofilm, and they tend to promote profibrotic environments and wound healing responses, generating abscesses during chronic osteomyelitis infections. ${ }^{48,49}$

Adaptive immune responses against bone infections include both T- and B-cell responses. Unfortunately, pathogens, such as $S$. aureus, have evolved numerous evasion mechanisms toward these responses, resulting in chronic osteomyelitis. For instance, in a porcine osteomyelitis infection model, it was observed that the antibody responses against intracellular $S$. aureus in biofilms are skewed to a predominantly type 1 and type 17 helper T cell biased immune response, which cannot effectively clear intracellular pathogens. ${ }^{50}$ Staphylococcus aureus can also efficiently manipulate B cells, affecting their survival and function via the secretion of staphylococcal protein A $(\mathrm{SpA})$, which associates with the $\mathrm{Fc} \gamma$ and $\mathrm{Fab}$ domains of certain antibodies, ${ }^{51-53}$ blocking antibody-mediated phagocytosis and simultaneously causing proliferative B-cell apoptosis. ${ }^{54,55}$

In addition, pathogen-specific antibodies produced by circulating plasmablasts and plasma cells are often not protective against chronic bone infections. ${ }^{56,57}$ Although further studies are needed to fully understand this, it may be that due to $\mathrm{SpA}$, interference antibodies secreted against $S$. aureus do not confer protection against reinfection or chronic musculoskeletal infections ${ }^{56}$ or that these antibodies are nonneutralizing antibodies. ${ }^{57}$ In fact, anti-S. aureus $\operatorname{IgG}$ responses against certain antigens can lead to mortal outcomes. ${ }^{58}$ Nonetheless, these antibody responses can be useful diagnostic and prognostic biomarkers for identifying orthopedic infections. ${ }^{59}$

\section{Bacterial Interactions with Skeletal Cells}

Bone is a mineralized organic matrix containing osteocytes, bone-forming osteoblasts, and bone-resorbing osteoclasts. All three bone cells are impacted directly and indirectly by S. aureus (Figure 1C).

Directly, SpA binding to TNF receptor-1 on osteoblasts results in an increase in apoptosis and a decrease in 
differentiation and calcium deposition of the osteoblasts. ${ }^{60,61}$ Moreover, internalization of $S$. aureus through fibronectin-binding protein $\mathrm{A} / \mathrm{B}-\alpha 5 \beta 1$ integrin bridging affects osteoblast viability and functioning. ${ }^{43,62}$ Both $S$. aureus internalization and $\mathrm{SpA}$ binding cause decreased bone formation and inhibition of matrix mineralization. ${ }^{60,61}$ Conversely, $S$. aureus infection increases periosteal bone formation by osteoblasts (as shown in rabbits) (Figure 2A) compared with noninfected controls (Figure 2B). ${ }^{63}$

Osteoclasts up-regulate their bone resorption capacity because of TNF and epidermal growth factor receptor activation through $\mathrm{SpA}$ secreted by $S$. aureus. ${ }^{65}$ This leads to resorption lacunae formation and necrotic bone pieces, as observed in biopsies of human osteomyelitis patients (Figure 2C) ${ }^{13,64}$ and in in vivo osteomyelitis models ${ }^{15}$ (Figure 2D). Indirectly, osteoclasts are activated and increase osteolysis activity by osteoblasts, osteocytes, and PMNs. These cell types secrete receptor activator of NF- $\mathrm{BB}$ ligand (RANK-L), which drives osteoclastogenesis and activates osteoclasts to resorb bone. Osteocytes do so in response to a neighboring osteocyte that underwent apoptosis $^{66}$ (eg, due to invasion of its lacunae by $S$. aureus). ${ }^{11}$ Moreover, osteoblasts up-regulate RANK-L expression when $\mathrm{SpA}$ is bound to TNF receptor-1 and by bacterial internalization, ${ }^{43,61}$ whereas PMNs up-regulate RANK-L secretion by toll-like receptor 4 activation. ${ }^{67}$ PMNs also drive osteoclastogenesis and bone resorption via osteoclast-mediated secretion of $\mathrm{IL}-8 .{ }^{64}$ Another contributor to osteoclastogenesis and osteoclast activity is the persistent inflammatory environment itself. This occurs initially because of the secretion of the proresorptive cytokines IL- 6 , TNF- $\alpha$, and IL- $1 \beta$ by immune cells and osteoblasts, ${ }^{16,43}$ and subsequently because of hypoxia resulting from the persistent inflammation. ${ }^{68}$

A crucial role of osteocytes is to mature and maintain the mineralized matrix, which is accomplished by their expression of enzymes capable of reversibly removing mineral and remodeling the organic phase of bone matrix, a process described as osteocytic osteolysis or perilacunar remodeling. ${ }^{66,69}$ The involvement of this process during osteomyelitis is currently poorly described, although matrix metalloproteinase expression was observed to be induced in $S$. aureus infected human osteocytes, ${ }^{36}$ suggesting that osteocytic osteolysis is affected by $S$. aureus. Another interesting function of osteocytes is their potential role in the recruitment of immune cells. A recent study demonstrated that human osteocyte-like cultures exposed to $S$. aureus resulted in the differential expression of $>1500$ genes, including the robust induction of a large number of chemokines and cytokines. ${ }^{36}$ Although classic PMN chemoattractants, such as CXCL1 and chemokine (C-C motif) ligand 5, were detected, CXC chemokine receptor 3 (CXCR3)-binding chemokines CXCL9, CXCL10, and CXCL11 were also expressed in abundance, suggesting the potential participation of osteocytes in the adaptive immune response to bacterial infection by recruiting cytotoxic and/or

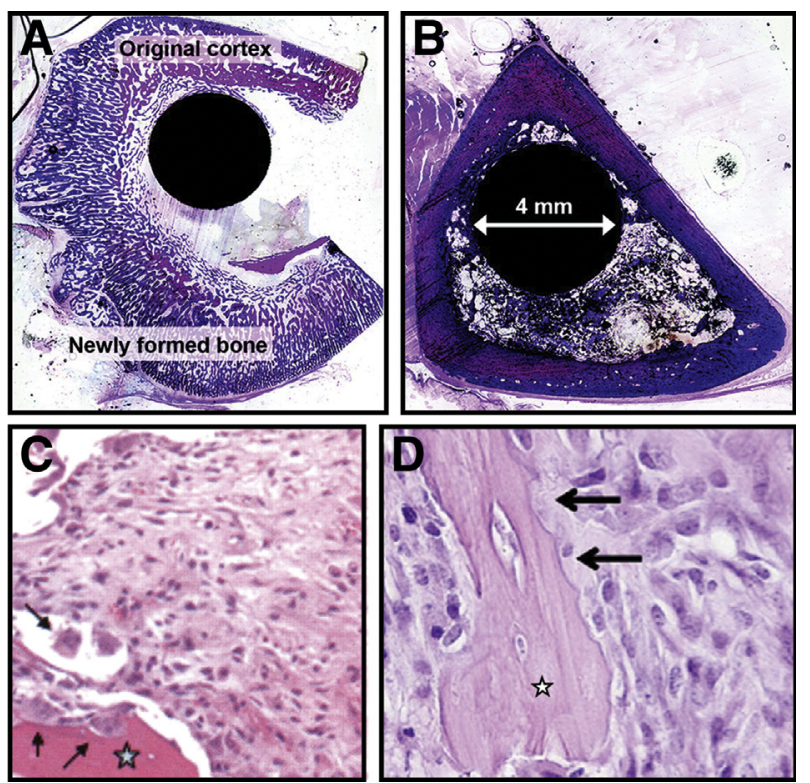

Figure 2 Staphylococcus aureus infection has a dramatic impact on bone. A: Infection causes periosteal bone formation, as observed in methyl methacrylate sections of an infected rabbit tibia stained with methylene blue/basic fuchsin. B: No periosteal bone is formed in control tibia samples. $\mathbf{C}$ and $\mathbf{D}$ : Furthermore, infection results in osteonecrosis and osteolysis by osteoclasts (arrows) actively resorbing bone (stars), as shown in hematoxylin and eosin stained histologic sections from a paraffin-embedded human biopsy ${ }^{64}$ (C) and mouse tibia (D). ${ }^{15}$ Panels $\mathbf{A}$ and $\mathbf{B}$ reprinted with permission from Mary Ann Liebert, Inc. ${ }^{63}$; panel $\mathbf{C}$ reprinted from Gaida et $\mathrm{al}^{64}$ with permission; panel $\mathbf{D}$ reprinted from Horst et $\mathrm{al}^{15}{ }^{15}$ with permission. Original magnification: $\times 200$ (C); $\times 40$ (D).

suppressive T-lymphocyte subsets to the infected sites. ${ }^{70}$ Further studies of the influence of the osteocyte in this regard will be of interest.

Taken together, S. aureus infection enhances osteoclastic bone resorption, ${ }^{63,67,68}$ possibly osteocytic osteolysis of bone, ${ }^{36}$ and inhibits bone formation, ${ }^{60,61}$ leading to an overall loss in bone tissue. ${ }^{13,15}$

\section{Conventional in Vitro Methods to Model Individual Aspects of Osteomyelitis}

Although human biopsies and animal osteomyelitis models have contributed significantly to our understanding of osteomyelitis, conventional in vitro methods remain of value. Some of the mainstays of this approach include bacterial cultures and cocultures with host cells, which are described below.

\section{Bacterial and Biofilm Cultures}

Biofilm growth in vivo can be mimicked with conventional models, such as microtiter plate-based models or flow displacement biofilm models, as reviewed recently. ${ }^{71}$ These models can be used for antimicrobial compound testing and measuring bacterial colonization/biofilm formation on 
various substrates. One of the most common methods currently used to assess anti-biofilm efficacy is the minimum biofilm eradication concentration assay, which is a 96-well biofilm system using polystyrene pegs. Bacterial biofilms grown on the pegs can be simultaneously challenged with multiple antibiotic combinations at different concentrations for assessing the bactericidal and/or bacteriostatic efficacies of these anitmicrobials. ${ }^{72}$

Conventional bacterial models can also be used to examine bacterial colonization on materials such as polymethyl methacrylate and the efficacy of antibacterial coatings. Examples of orthopedic implant-related materials and coatings that have been tested for bacterial colonization have recently been reviewed. ${ }^{73}$ An interesting antibacterial coating that has been tested is a tissue plasminogen activator-containing coating to activate plasminogen and increase fibrin degradation. ${ }^{74}$ Fibrin can form a layer on biomaterials and promote adherence of pathogens to the biomaterial. Fibrin is also a component of the $S$. aureus biofilm matrix that facilitates antibiotic resistance due to poor penetration of the antibiotic into the biofilm. It was shown that the tissue plasminogen activator-containing coating reduced bacterial adherence to the biomaterial. ${ }^{74}$ In addition, adherent bacteria were more susceptible to antibiotics because the bacteria were not protected by a fibrin matrix. $^{74}$ In a mouse model where $S$. aureus-infected implants were placed subcutaneously, the coating prevented biofilm-related infection. ${ }^{74}$

\section{Bacterial Coculture with Host Cells}

In an effort to increase the complexity and relevance of in vitro studies, bacterial cocultures with host immune or bone cells identified as key players in osteomyelitis have also been performed. For this review, a coculture is defined as a culture that combines bacteria with at least one host cell type.

Multiple groups have examined the effects of bacteria, usually $S$. aureus, on osteoblasts using two-dimensional cell culture models. ${ }^{43}$ To prevent bacterial overgrowth in static cultures, several techniques are routinely employed to remove extracellular bacteria. These include the use of antibiotics or the $S$. aureus-lysing enzyme lysostaphin, as well as rinsing to remove unbound bacteria. A variety of osteoblast coculture models have been developed using rodent and human cell lines, as well as human primary osteoblastic cells. ${ }^{43}$ Studies using S. aureus -infected human osteoblast cultures reported that the host cells underwent rapid and dramatic cell death after infection. ${ }^{75}$ One study examined the host cell response to several $S$. aureus strains at a fixed multiplicity of infection and showed that human primary osteoblasts exposed acutely or for short periods of time did not undergo cell death. ${ }^{40}$ Although relatively few intracellular bacteria were recovered, the primary cells secreted detectable levels of innate immune cell-relevant chemokines and cytokines, indicating the potential of osteoblasts to participate in innate immune responses and the utility of this model for studying this phenomenon. ${ }^{40}$ A study using bone explant-derived cells from the femoral heads of patients undergoing hip replacement surgery found that infections for up to 48 hours generated only low-level chemokine and cytokine responses, which the authors interpreted as indicating that osteoblasts may serve to internalize bacteria but not contribute significantly to the innate immune response..$^{43}$ It is possible that matching the source of human primary cells and the pathology under investigation (osteomyelitis) may influence experimental outcomes. More specifically, periprosthetic joint infection most often occurs in patients treated for primary osteoarthritis, and osteoblastic cells derived from these donors display different phenotypic and behavioral qualities, such as aberrant in vitro mineralization, to those derived from nonosteoarthritis patients treated for fragility fractures of the hip. ${ }^{76}$ Furthermore, in hip osteoarthritis patients, the femoral head is usually diseased and the cells derived from this site may, therefore, be aberrant in their responses ex vivo. Thus, a site more distal from the joint (eg, the intertrochanteric region of the proximal femur) may be a more suitable source of disease-naïve cells. In a study using human osteoarthritis proximal femur-derived osteoblasts differentiated to an osteocyte-like stage, no cell death effect was observed in response to $S$. aureus infection for up to 30 days. ${ }^{36}$ Staphylococcus aureus formed small colony variant associated with the up-regulation of sigma B activity, consistent with establishment of a persistent intracellular infection. This correlated with observations of $S$. aureus bacteria inside viable osteocytes in clinical periprosthetic joint infection bone specimens. ${ }^{36}$ This model allows the study of both the host response and adaptation of the bacteria to intracellular infection.

Other studies have incorporated foreign biomaterials into the infection model. A typical application is the coculture of $S$. aureus and osteoblasts on a biomaterial surface to model the so-called race for the surface. ${ }^{77}$ Herein, the idea is that if host cells colonize the biomaterial first, bacterial adhesion is prevented. One way to study the race for the surface is by seeding a flow chamber with both staphylococci and osteoblasts. ${ }^{77}$ By using this method, different coatings that prevent bacterial adhesion and subsequently promote more host cell attachment can be studied, such as a coating containing the antibiotic levofloxacin. ${ }^{78}$ Biomaterials coated with levofloxacin had fewer adherent $S$. aureus compared with a non-levofloxacin-coated equivalent, and this enabled colonization by preosteoblasts. ${ }^{78}$

The effect of $S$. aureus on osteoblast-induced osteoclastogenesis has also been studied in cocultures. These studies revealed that bacterial surface proteins could drive osteoclast formation because formaldehyde-fixed $S$. aureus induced RANK-L expression ${ }^{61}$ and IL- $6^{60}$ secretion by osteoblasts. Subsequently, this imbalances bone remodeling in favor of bone resorption. ${ }^{60}$ Furthermore, cocultures 
of $S$. aureus with osteoclasts have been performed; osteoclasts were seeded onto an inorganic crystalline calcium phosphate matrix mimicking bone, in presence of $S$. aureus. ${ }^{79}$ The infection promoted multinuclear osteoclast formation, which had a cellular area fourfold higher than noninfected osteoclasts and an increased bone resorption capacity, ${ }^{80}$ resulting from activation of the NF- $\kappa \mathrm{B}$ pathway by $S$. aureus. ${ }^{79}$ Therefore, targeting osteoclast activity using antiresorptive drugs, such as bisphosphonates $^{81}$ or denosumab (a monoclonal antibody targeting RANK-L), ${ }^{82}$ may be a means to prevent infection-induced osteolysis. Bisphosphonates or denosumab is effective in patients with mandibular osteomyelitis, ${ }^{81,82}$ but systemic administration of these antiresorptive drugs can also cause osteonecrosis of the jaw, ${ }^{83,84}$ indicating that further studies into antiresorptive drugs as a treatment option for osteomyelitis are required.

Bacterial biofilms can also be cocultured with immune cells. Immature and mature biofilms have been cocultured with $\mathrm{PMNs}^{85}$ to assess phagocytosis of biofilm-resident bacteria and the migration of PMNs to the biofilm. PMNs migrated toward the biofilm and engaged in phagocytosis of the biofilm, especially when the biofilm was in an immature state ( $<6$ days old). Mature biofilm was less sensitive to PMN attack than immature biofilm because 15-day-old biofilm was subjected to significantly less phagocytosis by PMNs than 2- and 6-day-old biofilms. ${ }^{85}$ A possible reason for this may be that the ECM covering biofilm matures over time, thus preventing PMNs from reaching the bacteria in resident mature biofilm. ${ }^{85}$

To our knowledge, only one multicellular model involving bacteria cocultured with both bone and host immune cells has been reported. To investigate competition for the surface of a polymethyl methacrylate plate, bacteria (S. aureus, Staphylococcus epidermidis, or Pseudomonas aeruginosa) were cultured in a flow chamber with an osteoblast cell line in the presence or absence of macrophages. It was shown that colonization of the polymethyl methacrylate plate by osteoblasts did not increase in the presence of macrophages, and it was primarily colonized by bacteria. ${ }^{86}$ This is in line with clinical observations where, despite host cell presence, bacteria win the race for the surface. The presence of macrophages did prolong the survival of osteoblasts in the multicellular cultures with either $S$. aureus or $P$. aeruginosa, and osteoblasts were able to grow and spread in the presence of low-virulence $S$. epidermidis. ${ }^{86}$ Future studies using such a multicellular model and testing different biomaterials would be of interest.

Although conventional models are of great use, they can only model the following aspects of osteomyelitis: biofilm formation and interactions of bacteria with one or multiple host cell types (Table 1). To resemble bone tissue, fibrous encapsulation, complex interactions between bacteria and multiple host cells, and osteomyelitis-induced bone abscesses with a necrotic core, more sophisticated systems, such as 3D in vitro systems, will be of immense value.

\section{Current 3D in Vitro Infection Models}

$3 \mathrm{D}$ in vitro systems are becoming a standard in many areas of biology, including infectious disease research. ${ }^{87} 3 \mathrm{D}$ cell culture structures can be generated by using scaffold-based or scaffold-free methods (eg, forced floating or hanging drop methods). ${ }^{88}$ Because the cells grow in a $3 \mathrm{D}$ environment composed of an ECM, cells in 3D in vitro models can have complex interactions not only with each other but also with the ECM. Therefore, cells in 3D culture do not lose their cell polarity, ${ }^{89}$ have an improved viability, ${ }^{90}$ and have morphologic features similar to cells observed in vivo. ${ }^{91,92}$ Furthermore, an advantage of 3D cell culture models over animal models, including humanized mice, is that human cells and fluids can be used. This is specifically of interest because $S$. aureus has some human-specific functions (eg, it was shown that staphylokinase has little activity toward murine plasminogen compared with the activity toward human plasminogen). ${ }^{93}$

3D models developed for other infections may contain relevant information for the development of an in vitro osteomyelitis model. Below, recent examples of $3 \mathrm{D}$ in vitro infection models based on organoids, rotating wall vessel (RWV) bioreactors, microcolonies in collagen gels, bacteria-containing printable inks, human skin equivalents, ex vivo models, microfluidic 3D models, and a 3D osteomyelitis model are discussed. Figure 3 illustrates these 3D in vitro infection models.

Infected organoid cultures have been used to study hostmicrobe interactions for multiple pathogens. Organoids are simplified versions of organs, which in a matrix with appropriate environmental cues grow from single stem cells given their self-organizing capacity. Figure $3 \mathrm{~A}$ illustrates a gastric organoid culture with Helicobacter pylori. The gastric organoids are grown from gastric stem cells, and this model has been used to study infection-induced changes in gastric epithelial cells. ${ }^{94}$ It has been demonstrated that

Table 1 Aspects of Osteomyelitis That Are Achievable in Conventional or Theoretically Achievable in 3D Models

\begin{tabular}{lll}
\hline Aspects of osteomyelitis & $\begin{array}{l}\text { Conventional } \\
\text { models }\end{array}$ & $\begin{array}{l}3 \mathrm{D} \\
\text { models }\end{array}$ \\
\hline $\begin{array}{l}\text { Biofilm formation } \\
\begin{array}{l}\text { Coculturing bacteria with } \\
\quad \text { one other cell type }\end{array}\end{array}$ & $\sqrt{ }$ & $\sqrt{ }$ \\
$\begin{array}{l}\text { Coculturing bacteria } \\
\text { with multiple cell types }\end{array}$ & $\sqrt{ }$ & \\
$\begin{array}{l}\text { Modeling in vivo bone tissue } \\
\begin{array}{l}\text { Generation of a fibrous } \\
\text { encapsulation around }\end{array}\end{array}$ & $\mathrm{X}$ & $\sqrt{ }$ \\
$\quad \begin{array}{l}\text { a 3D structure } \\
\text { Complex interactions between } \\
\text { bacteria and multiple cell types }\end{array}$ & $\mathrm{X}$ & $\sqrt{ }$ \\
A 3D structure with a necrotic core & $\mathrm{X}$ & $\sqrt{ }$ \\
\hline
\end{tabular}

3D, three dimensional. 
H. pylori infection causes up-regulation of the NF- $\kappa \mathrm{B}$ pathway in infected gastric organoids and, subsequently, an increase in IL-8, a neutrophil chemoattractant that promotes inflammation. ${ }^{94}$ In a more complex model, intestinal organoids from a human embryonic stem cell line were used to simulate Escherichia coli intestinal infection. The E. coli infected organoid was subsequently challenged with PMNs to thoroughly examine innate immune responses, such as reactive oxygen species production. ${ }^{95}$ Interestingly, the $E$. coli infection resulted in reactive oxygen species production by PMNs and migration of PMNs, but bacterial numbers did not decrease. ${ }^{95}$

Another method to obtain a 3D organ structure is by using the RWV bioreactor. ${ }^{103}$ Cells are first grown in a monolayer and left to either aggregate onto a scaffold, such as ECM-coated microcarrier beads, then transferred into the RWV bioreactor, or self-aggregate by directly transferring the cells into the RWV bioreactor. ${ }^{103,104}$ In the RWV bioreactor, cells are subjected to a low shear force and fall gently in a restricted orbit, which first promotes 3D cell aggregation and then differentiation. ${ }^{103,104}$ To study hostpathogen interactions with the RWV bioreactor, 3D aggregates have been formed for tissues, such as lung, bladder, and intestinal tissue. ${ }^{103} 3 \mathrm{D}$ intestinal aggregates were used to study Salmonella enterica serovar typhimurium infection $^{92}$ (Figure 3B). In this study, either RWV bioreactorgenerated 3D intestinal aggregates or a monolayer culture of small intestinal epithelial cells (standardly used) was infected with $S$. enterica serovar typhimurium. Salmonella was less able to adhere to and invade the intestinal 3D aggregates compared with the monolayer of cells. ${ }^{92}$ It was concluded that the intestinal 3D aggregates more accurately replicate the in vivo environment, where most $S$. enterica serovar typhimurium remain extracellular. ${ }^{92}$ Similar results

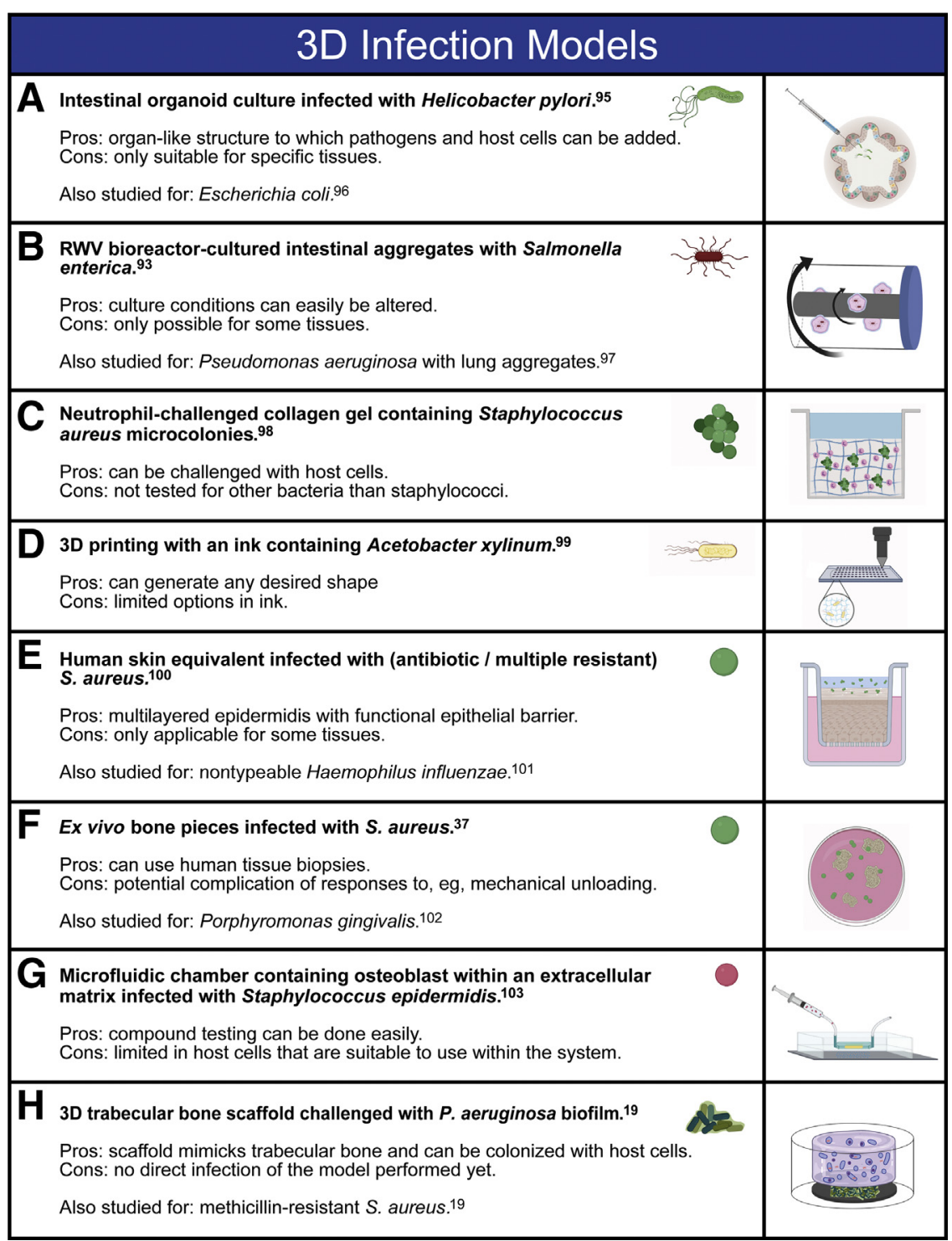

Figure 3 A summary of three-dimensional (3D) infection models and the pros and cons of each model are listed. These 3D in vitro infection models include an intestinal organoid culture (A), ${ }^{94,95}$ rotating wall vessel (RWV) bioreactor-cultured intestinal aggregates (B), ${ }^{92,96}$ Staphylococcus aureus microcolonies in collagen gels (C), ${ }^{97}$ 3D printing with bacteria-containing inks (D), ${ }^{98}$ human skin equivalents $(\mathbf{E}),{ }^{99,100}$ ex vivo bone models $(\mathbf{F}),{ }^{36,101}$ microfluidic 3D models $(\mathbf{G}),{ }^{102}$ and a 3D trabecular bone model $(\mathbf{H}) .{ }^{18}$ Images in $\mathbf{A}-\mathbf{H}$ were partially generated with BioRender (Toronto, ON, Canada). 
were observed for RWV bioreactor-formed lung aggregates infected with $P$. aeruginosa. In sharp contrast, monolayer cells were easily penetrable by $P$. aeruginosa, demonstrating that the RWV bioreactor-formed aggregates allowed for more in vivo-like infection by the bacterium given that the aggregates had more in vivo-like tight-junction complexes. $^{96}$

Staphylococcus aureus microcolonies in a collagen gel supplemented with human fibrinogen have been developed to examine phagocyte-microbe interactions ${ }^{97}$ (Figure 3C). Supplementation of the collagen gel with fibrinogen was performed to facilitate fibrin-dependent formation of an inner pseudocapsule around the staphylococcal microcolony and an outer dense microcolony-associated mesh surrounding the pseudocapsule. ${ }^{97}$ The inner pseudocapsule formation was shown to be partially coagulase dependent, and the formation of the outer microcolony-associated mesh depended on von Willebrand factor-binding protein. ${ }^{97}$ When challenged with PMNs, the staphylococcal microcolonies were protected by the inner pseudocapsule and the outer dense microcolony-associated mesh against PMN infiltration. ${ }^{97}$

Also, 3D printing bacteria-containing ink into specific shapes is possible. ${ }^{98}$ Acetobacter xylinum, which produce bacterial cellulose, has been incorporated into hydrogel ink with hyaluronic acid, k-carrageenan, and fumed silica (Figure 3D). This bacteria-laden hydrogel ink was not toxic for the bacteria and has successfully been 3D printed into various shapes. In addition, because the bacteria present within the hydrogel retained their metabolic capacity, this technology resulted in functional materials that may be used for biomedical applications. ${ }^{98}$

Infection models examining the interactions between skin commensals, such as staphylococci and the epidermis, have been performed with human skin equivalents (HSEs). HSE cultures are developed by layering fibroblasts and keratinocytes, and then promoting their differentiation via air exposure. ${ }^{99}$ This generates HSEs consisting of a dermis and multilayered epidermis, with a functional epithelial barrier that blocks the entrance of the bacteria into the dermis. ${ }^{99}$ To infect the HSE, a bacterial suspension is applied on top of the model and the bacteria, in this case $S$. aureus, are allowed to colonize the $\mathrm{HSE}^{99}$ (Figure 3E). A similar approach is used to study airway infection; a bronchial epithelial model was used to clarify changes occurring to the bronchial epithelium in response to nontypeable Hemophilus influenzae infection, which was applied apically. ${ }^{100}$ Interestingly, nontypeable $H$. influenzae appeared to specifically migrate toward the stromal compartment of the bronchial epithelial model where the bacterium secreted a lipid-based structure. ${ }^{100}$

Ex vivo models have been established to investigate inflammatory bone destruction. For this model, 1-mm-thick murine mandibular slices were cultured in an air-liquid interface. Cells continued to proliferate, and protein synthesis was unaltered. Tissue was not infected with bacteria, but inflammation was achieved by supplementing media with lipopolysaccharide from Porphyromonas gingivalis, resulting in an increased number of osteoclasts in the ex vivo culture. ${ }^{101}$ Another study used an ex vivo human bone infection model for the investigation of osteocyte-bacterium interactions $^{36}$ (Figure 3F). Fresh bone fragments without bone marrow, obtained from patients with femoral fracture $\left(1 \mathrm{~mm}^{3}\right.$ in size $)$ were cultured with $S$. aureus for 12 hours to achieve infection. Interestingly, $S$. aureus invaded osteocytes and lacunae of the ex vivo bone fragment, and the host cells responded in a manner similar to that of an in vitro differentiated two-dimensional culture of human primary osteocyte-like cells exposed to $S$. aureus. ${ }^{36}$ It was proposed that osteocytes may be an ideal host cell for long-term survival of the bacterium, where it adopts a small colony variant phenotype. ${ }^{36}$

A microfluidic 3D model has also been generated that promotes cells to form a 3D structure given the confined space and the microcirculation of nutrients and waste products in this system. For its development, a layer of human fibronectin, S. epidermidis, and osteoblasts were applied into the microfluidic device. ${ }^{102}$ This resulted in an infected bone tissue model consisting of osteoblasts in a self-produced ECM of collagen fibers and calcium phosphate crystals, together with $S$. epidermidis forming biofilm $^{102}$ (Figure 3G). This model allows the testing of treatments, such as antibiotics or wound-healing accelerators, by placing the microfluidic 3D model on inkjet-printed micropatterns containing the treatment. ${ }^{102}$ This model was used to test rifampicin-eluting biphasic calcium phosphate-containing beads, and it was demonstrated that these beads promoted osteoblast proliferation and ECM production, while simultaneously preventing biofilm formation. $^{102}$

For the evaluation of the effect of biofilms on hematopoiesis during bone marrow infection, a 3D osteomyelitis model was developed $^{18}$ (Figure 3H). More specifically, this model is a bone marrow analog that consists of a cationized bovine serum albumin scaffold resembling trabecular bone seeded with hematopoietic stem cells and mesenchymal stromal cells to mimic bone marrow. To infect this bone marrow analog, it was cocultured with a biofilm of methicillin-resistant $S$. aureus or $P$. aeruginosa grown on a titanium plate as a clinically relevant implant material. Pseudomonas aeruginosa caused cell death of both hematopoietic stem cells and mesenchymal stromal cells, whereas methicillin-resistant $S$. aureus stimulated IL-6 secretion by mesenchymal stromal cells and impaired differentiation of hematopoietic stem cells. ${ }^{18}$ To the best of our knowledge, this is the only reported 3D in vitro model realistically mimicking osteomyelitis pathophysiology. This model serves as an excellent starting point for further 3D osteomyelitis in vitro model development. 


\section{Outlook for in Vitro 3D Osteomyelitis Model Development}

The previously described 3D models in other areas of infectious diseases offer great opportunities to translate the technological possibilities of 3D models to more faithfully model osteomyelitis. ${ }^{19,37,93,95-103}$

The previously described cationized bovine serum albumin scaffold developed by Raic et $\mathrm{al}^{18}$ offers an excellent starting point because it resembles bone marrow. Other studies have shown that such scaffolds could additionally be seeded with osteoblasts and osteoclasts, ${ }^{105}$ in which osteoblasts could form bone, and osteoclasts could resorb bone. Furthermore, it would be interesting to adapt a long-term ex vivo mechanically loading culture, such as the Zetos system, for the study of osteomyelitis. ${ }^{106}$ With the Zetos system, 3D cancellous bone tissue can be maintained ex vivo under physiological conditions, and loading and/or treatment with a variety of biochemical interventions can be applied. ${ }^{106}$ Using the Zetos system in combination with micro-computed tomography (or equivalent imaging technique), bone remodeling in response to infection could be monitored that would enable longitudinal observations of bone changes over time and response to therapy. Another interesting option would be to use the RWV bioreactor to culture sequestra from bone or bone mimics, and coculture with host cells to 3D model osteomyelitis. Once a source of the infection is present, the model may be exposed to different immune cells at multiple time points. Poor diffusion of nutrients, waste, and oxygen are traditionally considered complications for 3D models, ${ }^{88}$ but osteomyelitis-induced bone abscesses frequently contain such areas, which could thus be readily accommodated in these model systems.

\section{Conclusions}

The key features of osteomyelitis from the perspective of the pathogen include biofilm formation; SAC formation ${ }^{22,23}$; intracellular infection; small colony variant phenotypes ${ }^{35,36,39}$; and the invasion of the submicron channels of the canaliculi network. ${ }^{11,30}$ Immune responses and antibiotic therapy are often ineffective against bacteria in these locations, leading to chronic recurrent osteomyelitis and a skewing of bone remodeling in favor of osteolysis. $^{60,61,63,67,68}$ Osteocytes themselves may also contribute to bone degradation in infection through the secretion of matrix metalloproteinases. ${ }^{36}$

Multicellular, 3D in vitro models of osteomyelitis have now also emerged as an exciting option to study the pathology of osteomyelitis using human cells, which offers promise in the advancement of our understanding of this disease, while also reducing animal use.

\section{References}

1. Lew DP, Waldvogel FA: Osteomyelitis. Lancet 2004, 364:369-379
2. Tong SY, Davis JS, Eichenberger E, Holland TL, Fowler VG Jr: Staphylococcus aureus infections: epidemiology, pathophysiology, clinical manifestations, and management. Clin Microbiol Rev 2015, 28:603-661

3. Walter G, Kemmerer M, Kappler C, Hoffmann R: Treatment algorithms for chronic osteomyelitis. Dtsch Arztebl Int 2012, 109: 257-264

4. Calhoun JH, Manring MM, Shirtliff M: Osteomyelitis of the long bones. Semin Plast Surg 2009, 23:59-72

5. McNally M, Nagarajah K: (iv) Osteomyelitis. Orthop Traumatol 2010, 24:416-429

6. Govaert GAM, Kuehl R, Atkins BL, Trampuz A, Morgenstern M, Obremskey WT, Verhofstad MHJ, McNally MA, Metsemakers WJ Diagnosing fracture-related infection: current concepts and recommendations. J Orthop Trauma 2020, 34:8-17

7. Metsemakers WJ, Morgenstern M, McNally MA, Moriarty TF, McFadyen I, Scarborough M, Athanasou NA, Ochsner PE, Kuehl R, Raschke M, Borens O, Xie Z, Velkes S, Hungerer S, Kates SL, Zalavras C, Giannoudis PV, Richards RG, Verhofstad MHJ: Fracturerelated infection: a consensus on definition from an international expert group. Injury 2018, 49:505-510

8. Tiemann A, Hofmann GO, Krukemeyer MG, Krenn V, Langwald S: Histopathological Osteomyelitis Evaluation Score (HOES): an innovative approach to histopathological diagnostics and scoring of osteomyelitis. GMS Interdiscip Plast Reconstr Surg DGPW 2014, 3:1-12

9. Parvizi J, Tan TL, Goswami K, Higuera C, Della Valle C, Chen AF, Shohat N: The 2018 definition of periprosthetic hip and knee infection: an evidence-based and validated criteria. J Arthroplasty 2018, 33:1309-13014 e2

10. Conterno LO, Turchi MD: Antibiotics for treating chronic osteomyelitis in adults. Cochrane Database Syst Rev 2013, 9: CD004439

11. de Mesy Bentley KL, Trombetta R, Nishitani K, Bello-Irizarry SN, Ninomiya M, Zhang L, Chung HL, McGrath JL, Daiss JL, Awad HA Kates SL, Schwarz EM: Evidence of Staphylococcus aureus deformation, proliferation, and migration in canaliculi of live cortical bone in murine models of osteomyelitis. J Bone Miner Res 2017, 32: 985-990

12. Klosterhalfen B, Peters KM, Tons C, Hauptmann S, Klein CL, Kirkpatrick CJ: Local and systemic inflammatory mediator release in patients with acute and chronic posttraumatic osteomyelitis. J Trauma 1996, 40:372-378

13. Ochsner PE, Hailemariam S: Histology of osteosynthesis associated bone infection. Injury 2006, 37:S49-S58

14. Wagner C, Kotsougiani D, Pioch M, Prior B, Wentzensen A, Hansch GM: T lymphocytes in acute bacterial infection: increased prevalence of $\mathrm{CD} 11 \mathrm{~b}(+)$ cells in the peripheral blood and recruitment to the infected site. Immunology 2008, 125:503-509

15. Horst SA, Hoerr V, Beineke A, Kreis C, Tuchscherr L, Kalinka J, Lehne S, Schleicher I, Kohler G, Fuchs T, Raschke MJ, Rohde M, Peters G, Faber C, Loffler B, Medina E: A novel mouse model of Staphylococcus aureus chronic osteomyelitis that closely mimics the human infection: an integrated view of disease pathogenesis. Am J Pathol 2012, 181:1206-1214

16. Yoshii T, Magara S, Miyai D, Nishimura H, Kuroki E, Furudoi S, Komori T, Ohbayashi C: Local levels of interleukin-1 $\beta,-4,-6$, and tumor necrosis factor $\alpha$ in an experimental model of murine osteomyelitis due to Staphylococcus aureus. Cytokine 2002, 19:59-65

17. Breslin S, O'Driscoll L: Three-dimensional cell culture: the missing link in drug discovery. Drug Discov Today 2013, 18:240-249

18. Raic A, Riedel S, Kemmling E, Bieback K, Overhage J, LeeThedieck C: Biomimetic 3D in vitro model of biofilm triggered osteomyelitis for investigating hematopoiesis during bone marrow infections. Acta Biomater 2018, 73:250-262

19. Gristina AG: Biomaterial-centered infection: microbial adhesion versus tissue integration. Science 1987, 237:1588-1595 
20. Hudson MC, Ramp WK, Frankenburg KP: Staphylococcus aureus adhesion to bone matrix and bone-associated biomaterials. FEMS Microbiol Lett 1999, 173:279-284

21. Giavaresi G, Borsari V, Fini M, Giardino R, Sambri V, Gaibani P, Soffiatti R: Preliminary investigations on a new gentamicin and vancomycin-coated PMMA nail for the treatment of bone and intramedullary infections: an experimental study in the rabbit. J Orthop Res 2008, 26:785-792

22. Brandt SL, Putnam NE, Cassat JE, Serezani CH: Innate immunity to Staphylococcus aureus: evolving paradigms in soft tissue and invasive infections. J Immunol 2018, 200:3871-3880

23. Inzana JA, Schwarz EM, Kates SL, Awad HA: A novel murine model of established Staphylococcal bone infection in the presence of a fracture fixation plate to study therapies utilizing antibiotic-laden spacers after revision surgery. Bone 2015, 72:128-136

24. Cheng AG, DeDent AC, Schneewind O, Missiakas D: A play in four acts: Staphylococcus aureus abscess formation. Trends Microbiol 2011, 19:225-232

25. Cheng AG, McAdow M, Kim HK, Bae T, Missiakas DM, Schneewind O: Contribution of coagulases towards Staphylococcus aureus disease and protective immunity. PLoS Pathog 2010, 6: e1001036

26. Kobayashi SD, Malachowa N, DeLeo FR: Pathogenesis of Staphylococcus aureus abscesses. Am J Pathol 2015, 185:1518-1527

27. Thomer L, Schneewind O, Missiakas D: Pathogenesis of Staphylococcus aureus bloodstream infections. Annu Rev Pathol 2016, 11: 343-364

28. Farnsworth CW, Schott EM, Benvie AM, Zukoski J, Kates SL, Schwarz EM, Gill SR, Zuscik MJ, Mooney RA: Obesity/type 2 diabetes increases inflammation, periosteal reactive bone formation, and osteolysis during Staphylococcus aureus implant-associated bone infection. J Orthop Res 2018, 36:1614-1623

29. Flemming HC, Wingender J, Szewzyk U, Steinberg P, Rice SA, Kjelleberg S: Biofilms: an emergent form of bacterial life. Nat Rev Microbiol 2016, 14:563-575

30. de Mesy Bentley KL, MacDonald A, Schwarz EM, Oh I: Chronic osteomyelitis with Staphylococcus aureus deformation in submicron canaliculi of osteocytes: a case report. JBJS Case Connect 2018, 8:e8

31. Oliveira D, Borges A, Simoes M: Staphylococcus aureus toxins and their molecular activity in infectious diseases. Toxins (Basel) 2018, 10:252

32. Kavanagh N, Ryan EJ, Widaa A, Sexton G, Fennell J, O'Rourke S, Cahill KC, Kearney CJ, O'Brien FJ, Kerrigan SW: Staphylococcal osteomyelitis: disease progression, treatment challenges, and future directions. Clin Microbiol Rev 2018, 31:e00084-17

33. Dohin B, Gillet Y, Kohler R, Lina G, Vandenesch F, Vanhems P, Floret D, Etienne J: Pediatric bone and joint infections caused by Panton-Valentine leukocidin-positive Staphylococcus aureus. Pediatr Infect Dis J 2007, 26:1042-1048

34. Kubica M, Guzik K, Koziel J, Zarebski M, Richter W, Gajkowska B, Golda A, Maciag-Gudowska A, Brix K, Shaw L, Foster T, Potempa J: A potential new pathway for Staphylococcus aureus dissemination: the silent survival of $\mathrm{S}$. aureus phagocytosed by human monocytederived macrophages. PLoS One 2008, 3:e1409

35. Jevon M, Guo C, Ma B, Mordan N, Nair SP, Harris M, Henderson B, Bentley G, Meghji S: Mechanisms of internalization of Staphylococcus aureus by cultured human osteoblasts. Infect Immun 1999, 67: $2677-2681$

36. Yang D, Wijenayaka AR, Solomon LB, Pederson SM, Findlay DM, Kidd SP, Atkins GJ: Novel insights into Staphylococcus aureus deep bone infections: the involvement of osteocytes. mBio 2018, 9: $\mathrm{e} 00415-\mathrm{e} 00418$

37. Edwards AM, Potts JR, Josefsson E, Massey RC: Staphylococcus aureus host cell invasion and virulence in sepsis is facilitated by the multiple repeats within FnBPA. PLoS Pathog 2010, 6:e1000964

38. Garzoni C, Kelley WL: Staphylococcus aureus: new evidence for intracellular persistence. Trends Microbiol 2009, 17:59-65
39. Krauss JL, Roper PM, Ballard A, Shih CC, Fitzpatrick JAJ, Cassat JE, Ng PY, Pavlos NJ, Veis DJ: Staphylococcus aureus infects osteoclasts and replicates intracellularly. mBio 2019, 10: e02447-19

40. Strobel M, Pfortner H, Tuchscherr L, Volker U, Schmidt F, Kramko N, Schnittler HJ, Fraunholz MJ, Loffler B, Peters G, Niemann S: Post-invasion events after infection with Staphylococcus aureus are strongly dependent on both the host cell type and the infecting S. aureus strain. Clin Microbiol Infect 2016, 22:799-809

41. Tuchscherr L, Heitmann V, Hussain M, Viemann D, Roth J, von Eiff C, Peters G, Becker K, Löffler B: Staphylococcus aureus smallcolony variants are adapted phenotypes for intracellular persistence. $\mathrm{J}$ Infect Dis 2010, 202:1031-1040

42. Chang MK, Raggatt LJ, Alexander KA, Kuliwaba JS, Fazzalari NL, Schroder K, Maylin ER, Ripoll VM, Hume DA, Pettit AR: Osteal tissue macrophages are intercalated throughout human and mouse bone lining tissues and regulate osteoblast function in vitro and in vivo. J Immunol 2008, 181:1232-1244

43. Josse J, Velard F, Gangloff SC: Staphylococcus aureus vs. osteoblast: relationship and consequences in osteomyelitis. Front Cell Infect Microbiol 2015, 5:85

44. Dapunt U, Maurer S, Giese T, Gaida MM, Hansch GM: The macrophage inflammatory proteins MIP1alpha (CCL3) and MIP2alpha (CXCL2) in implant-associated osteomyelitis: linking inflammation to bone degradation. Mediators Inflamm 2014, 2014:728619

45. Rigby KM, DeLeo FR: Neutrophils in innate host defense against Staphylococcus aureus infections. Semin Immunopathol 2012, 34: 237-259

46. Brinkmann V, Reichard U, Goosmann C, Fauler B, Uhlemann Y, Weiss DS, Weinrauch Y, Zychlinsky A: Neutrophil extracellular traps kill bacteria. Science 2004, 303:1532-1535

47. Lu T, Kobayashi SD, Quinn MT, Deleo FR: A NET outcome. Front Immunol 2012, 3:365

48. Scherr TD, Heim CE, Morrison JM, Kielian T: Hiding in plain sight: interplay between staphylococcal biofilms and host immunity. Front Immunol 2014, 5:37

49. Scherr TD, Roux CM, Hanke ML, Angle A, Dunman PM, Kielian T: Global transcriptome analysis of Staphylococcus aureus biofilms in response to innate immune cells. Infect Immun 2013, 81:4363-4376

50. Jensen LK, Jensen HE, Koch J, Bjarnsholt T, Eickhardt S, Shirtliff M: Specific antibodies to Staphylococcus aureus biofilm are present in serum from pigs with osteomyelitis. In Vivo 2015, 29:555-560

51. Moks T, Abrahmsen L, Nilsson B, Hellman U, Sjoquist J, Uhlen M: Staphylococcal protein A consists of five IgG-binding domains. Eur J Biochem 1986, 156:637-643

52. Cedergren L, Andersson R, Jansson B, Uhlen M, Nilsson B: Mutational analysis of the interaction between staphylococcal protein A and human IgG1. Protein Eng 1993, 6:441-448

53. Schneewind O, Model P, Fischetti VA: Sorting of protein A to the staphylococcal cell wall. Cell 1992, 70:267-281

54. Graille M, Stura EA, Corper AL, Sutton BJ, Taussig MJ, Charbonnier JB, Silverman GJ: Crystal structure of a Staphylococcus aureus protein A domain complexed with the Fab fragment of a human IgM antibody: structural basis for recognition of B-cell receptors and superantigen activity. Proc Natl Acad Sci U S A 2000, 97:5399-5404

55. Goodyear CS, Silverman GJ: Death by a B cell superantigen: in vivo VH-targeted apoptotic supraclonal B cell deletion by a staphylococcal toxin. J Exp Med 2003, 197:1125-1139

56. Keener AB, Thurlow LT, Kang S, Spidale NA, Clarke SH, Cunnion KM, Tisch R, Richardson AR, Vilen BJ: Staphylococcus aureus protein A disrupts immunity mediated by long-lived plasma cells. J Immunol 2017, 198:1263-1273

57. Muthukrishnan G, Masters EA, Daiss JL, Schwarz EM: Mechanisms of immune evasion and bone tissue colonization that make Staphylococcus aureus the primary pathogen in osteomyelitis. Curr Osteoporos Rep 2019, 17:395-404 
58. Fowler VG, Allen KB, Moreira ED, Moustafa M, Isgro F, Boucher HW, Corey GR, Carmeli Y, Betts R, Hartzel JS, Chan IS, McNeely TB, Kartsonis NA, Guris D, Onorato MT, Smugar SS, DiNubile MJ, Sobanjo-ter Meulen A: Effect of an investigational vaccine for preventing Staphylococcus aureus infections after cardiothoracic surgery: a randomized trial. JAMA 2013, 309: $1368-1378$

59. Nishitani K, Beck CA, Rosenberg AF, Kates SL, Schwarz EM, Daiss JL: A diagnostic serum antibody test for patients with Staphylococcus aureus osteomyelitis. Clin Orthop Relat Res 2015, 473: 2735-2749

60. Claro T, Widaa A, McDonnell C, Foster TJ, O'Brien FJ, Kerrigan SW: Staphylococcus aureus protein A binding to osteoblast tumour necrosis factor receptor 1 results in activation of nuclear factor kappa B and release of interleukin-6 in bone infection. Microbiology 2013, 159:147-154

61. Widaa A, Claro T, Foster TJ, O'Brien FJ, Kerrigan SW: Staphylococcus aureus protein A plays a critical role in mediating bone destruction and bone loss in osteomyelitis. PLoS One 2012, 7:e40586

62. Claro T, Widaa A, O'Seaghdha M, Miajlovic H, Foster TJ, O'Brien FJ, Kerrigan SW: Staphylococcus aureus protein A binds to osteoblasts and triggers signals that weaken bone in osteomyelitis. PLoS One 2011, 6:e18748

63. Croes M, Boot W, Kruyt MC, Weinans H, Pouran B, van der Helm YJM, Gawlitta D, Vogely HC, Alblas J, Dhert WJA, Oner FC: Inflammation-induced osteogenesis in a rabbit tibia model. Tissue Eng Part C Methods 2017, 23:673-685

64. Gaida MM, Mayer B, Stegmaier S, Schirmacher P, Wagner C, Hänsch GM: Polymorphonuclear neutrophils in osteomyelitis: link to osteoclast generation and bone resorption. Eur J Inflamm 2012, 10: 413-426

65. Mendoza Bertelli A, Delpino MV, Lattar S, Giai C, Llana MN, Sanjuan N, Cassat JE, Sordelli D, Gomez MI: Staphylococcus aureus protein A enhances osteoclastogenesis via TNFR1 and EGFR signaling. Biochim Biophys Acta 2016, 1862:1975-1983

66. Prideaux M, Findlay DM, Atkins GJ: Osteocytes: the master cells in bone remodelling. Curr Opin Pharmacol 2016, 28:24-30

67. Chakravarti A, Raquil MA, Tessier P, Poubelle PE: Surface RANKL of Toll-like receptor 4-stimulated human neutrophils activates osteoclastic bone resorption. Blood 2009, 114:1633-1644

68. Arnett TR, Gibbons DC, Utting JC, Orriss IR, Hoebertz A, Rosendaal M, Meghji S: Hypoxia is a major stimulator of osteoclast formation and bone resorption. J Cell Physiol 2003, 196:2-8

69. Tsourdi E, Jahn K, Rauner M, Busse B, Bonewald LF: Physiological and pathological osteocytic osteolysis. J Musculoskelet Neuronal Interact 2018, 18:292-303

70. Groom JR, Luster AD: CXCR3 ligands: redundant, collaborative and antagonistic functions. Immunol Cell Biol 2011, 89:207-215

71. Coenye T, Nelis HJ: In vitro and in vivo model systems to study microbial biofilm formation. J Microbiol Methods 2010, 83:89-105

72. Dalecki AG, Crawford CL, Wolschendorf F: Targeting biofilm associated Staphylococcus aureus using resazurin based drugsusceptibility assay. J Vis Exp 2016, 111:e53925

73. Harris LG, Richards RG: Staphylococci and implant surfaces: a review. Injury 2006, 37:S3-S14

74. Kwiecinski J, Na M, Jarneborn A, Jacobsson G, Peetermans M, Verhamme P, Jin T: Tissue plasminogen activator coating on implant surfaces reduces Staphylococcus aureus biofilm formation. Appl Environ Microbiol 2016, 82:394-401

75. Mohamed W, Sommer U, Sethi S, Domann E, Thormann U, Schutz I, Lips KS, Chakraborty T, Schnettler R, Alt V: Intracellular proliferation of S. aureus in osteoblasts and effects of rifampicin and gentamicin on S. aureus intracellular proliferation and survival. Eur Cell Mater 2014, 28:258-268

76. Kumarasinghe DD, Sullivan T, Kuliwaba JS, Fazzalari NL, Atkins GJ: Evidence for the dysregulated expression of TWIST1, TGFbeta1 and SMAD3 in differentiating osteoblasts from primary hip osteoarthritis patients. Osteoarthritis Cartilage 2012, 20: 1357-1366

77. Subbiahdoss G, Pidhatika B, Coullerez G, Charnley M, Kuijer R, van der Mei HC, Textor M, Busscher HJ: Bacterial biofilm formation versus mammalian cell growth on titanium-based mono- and bifunctional coating. Eur Cell Mater 2010, 19:205-213

78. Cicuendez M, Doadrio JC, Hernandez A, Portoles MT, IzquierdoBarba I, Vallet-Regi M: Multifunctional pH sensitive 3D scaffolds for treatment and prevention of bone infection. Acta Biomater 2018, 65: $450-461$

79. Ren L-R, Wang Z-h, Wang H, He X-Q, Song M-G, Xu Y-Q: Staphylococcus aureus induces osteoclastogenesis via the NF- $\mathrm{B}$ signaling pathway. Med Sci Monit 2017, 23:4579-4590

80. Trouillet-Assant S, Gallet M, Nauroy P, Rasigade JP, Flammier S, Parroche P, Marvel J, Ferry T, Vandenesch F, Jurdic P, Laurent F: Dual impact of live Staphylococcus aureus on the osteoclast lineage, leading to increased bone resorption. J Infect Dis 2015, 211:571-581

81. Russell RG, Rogers MJ: Bisphosphonates: from the laboratory to the clinic and back again. Bone 1999, 25:97-106

82. Hallmer F, Korduner M, Moystad A, Bjornland T: Treatment of diffuse sclerosing osteomyelitis of the jaw with denosumab shows remarkable results: a report of two cases. Clin Case Rep 2018, 6: 2434-2437

83. Aghaloo TL, Felsenfeld AL, Tetradis S: Osteonecrosis of the jaw in a patient on denosumab. J Oral Maxillofac Surg 2010, 68:959-963

84. Hallmer F, Bjornland T, Nicklasson A, Becktor JP, Andersson G: Osteonecrosis of the jaw in patients treated with oral and intravenous bisphosphonates: experience in Sweden. Oral Surg Oral Med Oral Pathol Oral Radiol 2014, 118:202-208

85. Gunther F, Wabnitz GH, Stroh P, Prior B, Obst U, Samstag Y, Wagner C, Hansch GM: Host defence against Staphylococcus aureus biofilms infection: phagocytosis of biofilms by polymorphonuclear neutrophils (PMN). Mol Immunol 2009, 46:1805-1813

86. Subbiahdoss G, Fernandez IC, Domingues JF, Kuijer R, van der Mei HC, Busscher HJ: In vitro interactions between bacteria, osteoblast-like cells and macrophages in the pathogenesis of biomaterial-associated infections. PLoS One 2011, 6:e24827

87. Barrila J, Crabbe A, Yang J, Franco K, Nydam SD, Forsyth RJ, Davis RR, Gangaraju S, Ott CM, Coyne CB, Bissell MJ, Nickerson CA: Modeling host-pathogen interactions in the context of the microenvironment: three-dimensional cell culture comes of age. Infect Immun 2018, 86:e0282-18

88. Edmondson R, Broglie JJ, Adcock AF, Yang L: Three-dimensional cell culture systems and their applications in drug discovery and cellbased biosensors. Assay Drug Dev Technol 2014, 12:207-218

89. Birgersdotter A, Sandberg R, Ernberg I: Gene expression perturbation in vitro-a growing case for three-dimensional (3D) culture systems. Semin Cancer Biol 2005, 15:405-412

90. Antoni D, Burckel H, Josset E, Noel G: Three-dimensional cell culture: a breakthrough in vivo. Int J Mol Sci 2015, 16:5517-5527

91. Wang X, Sun L, Maffini MV, Soto A, Sonnenschein C, Kaplan DL: A complex 3D human tissue culture system based on mammary stromal cells and silk scaffolds for modeling breast morphogenesis and function. Biomaterials 2010, 31:3920-3929

92. Nickerson CA, Goodwin TJ, Terlonge J, Ott CM, Buchanan KL, Uicker WC, Emami K, LeBlanc CL, Ramamurthy R, Clarke MS, Vanderburg CR, Hammond T, Pierson DL: Three-dimensional tissue assemblies: novel models for the study of Salmonella enterica serovar Typhimurium pathogenesis. Infect Immun 2001, 69:7106-7120

93. Okada K, Ueshima S, Tanaka M, Fukao H, Matsuo O: Analysis of plasminogen activation by the plasmin-staphylokinase complex in plasma of alpha2-antiplasmin-deficient mice. Blood Coagul Fibrinolysis 2000, 11:645-655

94. Bartfeld S, Bayram T, van de Wetering M, Huch M, Begthel H, Kujala P, Vries R, Peters PJ, Clevers H: In vitro expansion of human gastric epithelial stem cells and their responses to bacterial infection. Gastroenterology 2015, 148:126-136.e6 
95. Karve SS, Pradhan S, Ward DV, Weiss AA: Intestinal organoids model human responses to infection by commensal and Shiga toxin producing Escherichia coli. PLoS One 2017, 12:e0178966

96. Carterson AJ, Honer zu Bentrup K, Ott CM, Clarke MS, Pierson DL, Vanderburg CR, Buchanan KL, Nickerson CA, Schurr MJ: A549 lung epithelial cells grown as three-dimensional aggregates: alternative tissue culture model for Pseudomonas aeruginosa pathogenesis. Infect Immun 2005, 73:1129-1140

97. Guggenberger C, Wolz C, Morrissey JA, Heesemann J: Two distinct coagulase-dependent barriers protect Staphylococcus aureus from neutrophils in a three dimensional in vitro infection model. PLoS Pathog 2012, 8:e1002434

98. Schaffner M, Ruhs PA, Coulter F, Kilcher S, Studart AR: 3D printing of bacteria into functional complex materials. Sci Adv 2017, 3: eaao6804

99. Haisma EM, Rietveld MH, de Breij A, van Dissel JT, El Ghalbzouri A, Nibbering PH: Inflammatory and antimicrobial responses to methicillin-resistant Staphylococcus aureus in an in vitro wound infection model. PLoS One 2013, 8:e82800

100. Marrazzo P, Maccari S, Taddei A, Bevan L, Telford J, Soriani M, Pezzicoli A: 3D reconstruction of the human airway mucosa in vitro as an experimental model to study NTHi infections. PLoS One 2016, 11:e0153985

101. Sloan AJ, Taylor SY, Smith EL, Roberts JL, Chen L, Wei XQ, Waddington RJ: A novel ex vivo culture model for inflammatory bone destruction. J Dent Res 2013, 92:728-734

102. Lee JH, Gu Y, Wang H, Lee WY: Microfluidic 3D bone tissue model for high-throughput evaluation of wound-healing and infectionpreventing biomaterials. Biomaterials 2012, 33:999-1006

103. Barrila J, Radtke AL, Crabbe A, Sarker SF, Herbst-Kralovetz MM, Ott CM, Nickerson CA: Organotypic 3D cell culture models: using the rotating wall vessel to study host-pathogen interactions. Nat Rev Microbiol 2010, 8:791-801

104. Radtke AL, Herbst-Kralovetz MM: Culturing and applications of rotating wall vessel bioreactor derived 3D epithelial cell models. J Vis Exp 2012, 62:e3868

105. Jeon OH, Panicker LM, Lu Q, Chae JJ, Feldman RA, Elisseeff JH: Human iPSC-derived osteoblasts and osteoclasts together promote bone regeneration in 3D biomaterials. Sci Rep 2016, 6:26761

106. Davies CM, Jones DB, Stoddart MJ, Koller K, Smith E, Archer CW, Richards RG: Mechanically loaded ex vivo bone culture system "Zetos": systems and culture preparation. Eur Cell Mater 2006, 11:57-75 